\title{
Determinants of Organizational Change Implementation Success: The Case of Ethiopian Commodity Exchange Authority
}

\author{
Temesgen Woldamanuel Wajebo
}

\begin{abstract}
The effect of many factors have been examined and suggested to make change implementation successful; however, organizations still report a high failure rate of their change initiatives. This high failure rates highlight the continuing need for further research to examine the factors influencing the success of organizational change implementation. As a result, the study attempted to examine the effect of internal communication, leadership, information communication technology usage, organizational culture and organizational change management method on the success of organizational change implementation construct. To undertake the study, the mixed research approach with cross- sectional time dimension was used. The data for the study was collected from 157 employees of Ethiopian commodity exchange authority using self-administered questinnaires. Both descriptive and inferencial methods were employed to undertake the analysis. From the inferencial method multiple regression model was applied. Principal component analysis was also used for testing factors reliability in composite factor construct and reduction of the multiple factors to a single composite factor.The study found that leadership, internal communication, organizational culture and organizational change management method have positive and significant effects on the success of organizational change implementation in the authority. In contrary, the effect of independent variable -information communication technology- on the success of organizational change implementation is not statistically significant. To be more specific, a one unit increase in leadership composite index, internal communication index, organizational culture index, and organizational change management method index will brings $0.958,0.61,0.42$ and 0.59 unit increment in Organizational change implementation success index holding other factors constant.
\end{abstract}

Keywords:organizational change, organizational change implementation success and factors influencing organizational change implementation.

DOI: $10.7176 / \mathrm{JAAS} / 75-01$

Publication date:August $31^{\text {st }} 2021$

Acronomy: ECXA-Ethiopian Commodity Exchange Authority, PhD-Doctor of Philosophy, ICT-Information Communication Technology, PAR-Participatory Action Research, ERA-Evaluatio,Re-Evaluation and Action, PValue-Probability value

\section{Introduction}

\subsection{Background of Study}

The management system used by a firm is a determining component of the firm's responsiveness to environmental changes because it determines the way a management perceives environmental challenges, diagnoses their impact on the firm, decides what to do and implements decisions (Ansoff \& McDonnell, 1990). The business environment is blustery (Ansoff, 1999) where stability and predictability has been replaced by rapid change and creativity. The discontinuous environment could be as a result of many factors, namely; technology advancement, competition and unpredictable international markets among main reasons. In this regard, it is crucial for today's leaders to develop a systematic approach to deal with managing strategic change implementation.

Change management incorporates appreciating the drivers of transformation both in the internal and external environment and also observing the beliefs and attitudes of people within the organization. Change within the organization may affect behavior, shared beliefs, the way work is done and the rules that shape mental models. Shared mental models are a part of organizational culture (Hayes, 2007). The dynamic business environment requires frequent changes in the way organizations operate structurally (Turner, 1999).

Even though the change implementation process is difficult and challenging, great efforts should be put in the implementation of change because of the future of organizations fully depends on the success of change projects. Why it is challenging is that because of change affects all aspects of an organization, including strategy, internal structure, processes, people's jobs and attitudes and overall culture of the organizations (Kanter et al., 1992). Thus, it needs to follow a clear method in order for change to be successful (Haidar, 2006).

Incontrary, the failure rate for change programs in organizations has been showed an extreme number, which is 70 percent of the change programmes failed (Keller and Aiken 2000; Senturia, Flees \& Maceda, 2008). In addition, more recent studies note the fact that this rate is not getting any better (Jansson, 2013; Rouse, 2011).

Bolman \& Deal (2005:454) claim that the reason for this much failure is ignoring softer human aspects like feelings, motivation and commitment. Furthermore, internal communication, leadership, change management 
method, systematic change method,information technology usage and organizational cultures are some of the factors influencing the success of change implementation (Al-Haddad and Kotnour, 2013). Several scholars also argued that leaders have a significat role in making effective change for an organization (Senior and Fleming, 2006 , Bennis, 1987 ). In addition to these, Kotnour (2011) found three enablers, which organization needs to have in order to enable successful change and enhanced organizational performance. These are knowledge and skills, resources and commitment. In addition, Dunphy and Stace (1993) argued that leaders need a method of change that optimaly fit with the particular situation (p. 905). With the high variation between organizations undergoing change, one change approach or method would not be suitable for all situations (Michel et al., 2016). One-size-fits all methods frequently result in failing change (Kotter \& Schlesinger, 2008). There fore, the failure rates debatably imply a lack of a valid framework for organizational change (By, 2005; Rafferty et al., 2013).

Although the failure rate of change initiatives is being common, the role of organization in society is dominating and the happening of change was not ignored (Kotter and Rathgeber's, 2006). However, in the organizational change literature, there has been a considerable disagreement regarding the most appropriate method to changing organizations, we cannot ignore the happening of change (Bamford \& Forrester, 2003). So that we need to continue to discuss the topic. To this end, it is needed to examine the determinants of organizational change implementation success in the case of Ethiopian Commodity Exchane Authority. Specifically the study seek to examine the effect of leaders, systematic change methods, internal communication, information technology (IT), organizational culture and change management methods in the success of an organization change implementation in Authority. To my knowledge, study has not been yet done on topic "Factors affecting the success of Organizational Change implementation: The Case of Ethiopian Commodity Exchange Authority"

\section{Literature Review}

\subsection{Theoretical Leteratures}

Several scholar and researchers appeared and prorogated the necessity of practical change for the successful performance of organizations. Some of them argued that organizations need to take some practical organizational changes in order to get the level of long - term success and sustainability (Burnes, 2004; By, 2005; Hailey \& Balogun, 2002; Kotter, 1996; Mintzberg, 1979; Moran \& Brightman, 2001). While talking about these practical steps for organizations, scholars and researchers have agreed that organizations need to accept, adopt and implement changes in their business model according to changing trends, technologies, customer preferences and future concerns.

Anderson and Ackerman (2001) suggest that the main three aspects of a comprehensive change strategy are content, people and process. Content refers to the strategy, systems, technologies, and work practices. People refer to humans involved in the change, and their behavior when implementing change. The deeper the organizational change, the more important it is for people to alter their own values and perspectives to align with the overall organizational perspective (Moran \& Brightman, 2001). The third aspect of change is process, representing the actions and procedures carried out to implement change. Therefore, the proper alignment between content, people and process is what leads to successful change

Literatures offer a broad range of definitions and examples of change enablers including: - a stated vision and goals for the change direction, defined roles of employees involved in change, leadership guidance or commitment in involvement, training employees and having strong human resources to measure and evaluate performance (Bridges ,2003; Griffith-Cooper \& King, 2007; Kenny, 2006). Proper planning and analysis also help to identify the gap between where the organization is now and where it wants to be. The organization needs to identify the environmental conditions required for the change plan to succeed (Hotek \& White, 1999; Kotter, 1996). Weber and Weber (2001) argue that people's perception of organizational readiness for change can also affect change success.

Organizations have to recognize that change without planning yields negative results; hence, they need to fully understand the possibility of getting positive and negative results of an action before it is initiated in the first place (Kanter et al., 1992; Kotter, 1996). Burnes \& Jackson (2011) argued that poor planning or lack of commitment to change are the reasons for failure of change implementation. Conner (1998) believes that organizations have to realize that the drivers of change are all connected and affect each other; any change action has a chain reaction that affects the whole organization.

\subsubsection{Leadership}

Leadership can be defined as a process whereby a person influences and directs others to accomplish a certain objective or achieve a common goal (Northouse, 2007). A leader is the person who makes sure that the organization is heading in the right direction (Winston, 2004). Leaders is person who have to make the right decisions at the right time to align the organization with the changing environment, and who motivate the people to work and implement the changes (Goleman, 2000; Haidar, 2006). Soderholm (1989) also argues that leadership is about the innovation of new ideas and new concepts that brings new desirable outcomes. The 
entrepreneurship, creativity and innovation embedded in leadership are very important to successfully managing change. In addition, Hamel (2007) believes that mobilizing talent, allocating resources, and formulating strategies are necessary for the organization's profitability and for maintaining the competitive advantage. According to Kouzes and Posner (1995) the five main leadership practices are modeling the way, inspiring a shared vision, challenging the process, enabling others to act, and encouraging the heart.

As defined by Griffith-Cooper and King (2007), change leadership refers to a "set of principles, techniques, or activities applied to the human aspects of executing change to influence intrinsic acceptance while reducing resistance" (p. 14). Change leaders are people with creative visions, who are able to foresee a new reality and how to get to it. Change leaders have to understand how their employees perceive change and ensure they accept the change and are ready for it. They have to motivate employee to take responsibility and be an active part of the change (Gioia et al., 2013; Van et al ., 2013). Kanter (2000) suggests that the classic skills for change leaders are "Tuning in to the environment, Challenging the prevailing organizational wisdom, communicating a compelling aspiration, building coalitions, Transferring ownership to a working team, Learning to preserve and Making everyone a hero" (p. 34).

According to Bennis and Nanus (1985) and Madanchian (2017), the most common measures to evaluate the effectiveness of a leader is examining the consequences of leaders' actions. Such as, improved group performance, improved subordinate job satisfaction, increased subordinate performance and commitment, improved decision-making and increased subordinate commitment to decisions, increased subordinate commitment to organizational goal, and willingness of subordinate to take additional responsibility will be used.

\subsubsection{Internal Communication}

Westwood and Linstead (2001) believes that organizational communication is among factors determining organizational effectiveness and the achievement of planned change. Chia and King (2001) defined organizational communication as the process by, which individuals stimulate meaning in the minds of other individuals by means of verbal or nonverbal messages in the context of a formal organization. Butcher and Atkinson (2001) have argued that the rhetoric of top-down change is limited and self-defeating because it offers an impoverished and isolationist system rendering of the processes of change; specially change upon subordinate groups. Countering this top-down rendering of change they argue that bottom-up approaches are both credible and practical. Yet on the other hand they note that the mainstream understanding of change is dominated by topdown approach , managerialist approach to change, which relies on a rational and hierarchical paradigm of organization.

Contrasting this top-down understanding of change with bottom-up accounts of change, Butcher and Atkinson (2001) argue that bottom-up accounts of change are distinctive insofar as they emphasize the power of individuals in creating organizational change. However, they observe that this focus on local actors tends to reduce the credibility, legitimacy and functional appeal of bottom-up accounts of change in the face of top-down rhetoric. Thus, they note that in comparison to top-down models of change, bottom-up accounts might appear to lack direction and application because of the local, political and often insubordinate nature of the actual processes of change. Yet despite this, Butcher and Atkinson (2001) argue that bottom-up models of change have very real and practical advantages to offer management practitioners.

\subsubsection{Organizational Culture}

According to Proch (2019), for an organization anticipating change, a conflict between the conservative group and the liberal group may slow down the process of change. Organizational culture is a concept, which describes the attitudes, experiences, beliefs and values of an organization (Wiener, 2018). An organization's culture can be a major strength when it is consistent with the strategy and thus can be a powerful driving force in implementation. According to Johnson and Scholes (2002), social processes can also create rigidities if an organization needs to change their strategy. Managing the strategy-culture relationship therefore requires sensitivity to the interaction between changes necessary to implement strategy and compatibility or fit between those change and the organizational culture (Pearce and Robinson, 2003). Public sector organizations are often portrayed as highly rigid and unable to cope with novelty and change (Lam, 2004, p. 118).

According to Meyer and Stensaker (2006), organizations need to develop capacity for change, by allocation and development of change and operational capabilities that sustain long term performance. Don Edward et al., (1996) observed that consistency increases ability to engage, up-skill managers, and more opportunities to build expertise in the selected methodology. Davidsson (2005) theorized that the goal of the change management program for employees is to make the people ready for change and conduct them to move to the new environment and map them to the new way of running the organization. New changes in turn in organizations brings new organizational roles and jobs descriptions for the employees (Lewis, 2006).

\subsubsection{Organizational Systems}

For institutions to effectively implement changes in their management, new systems are required to incorporate new management issues within the organization. The main challenge is thus not the acquisition of such systems but the compatibility of the new systems and the previous ones. Incompatibility would affect adoption of change 
implementation management. Similarly, Rogers (1995) affirms that certain innovations are closely interlinked, and, therefore, there exists a strong correlation between the previous experience of the subject with particular tools and the subsequent use of other applications.

Thus, those subjects with greater experience of a particular IT modify positively their perception of other similar technologies, increase their level of use, and even come to observe a pattern of conduct differentiated between them (Reed et al, 2000). In this way, the previous experience of the user in the systems is more important than experience in the change management sphere.

Igbaria (1993) demonstrated that previous user experience has a direct effect upon the degree of subsequent acceptance and success of change in management (Min and Galle, 2003). Similarly, it is indisputable that experience modifies certain perceptions of the individual with respect to the new technologies, such as perceived usefulness or ease of use, while the time and effort invested in their employment simultaneously diminish (Norman, 1998; Haider and Frensch. 1999). Shirani et al. (1994) identifeied experience in the technology field and external organizational culture as relevant variables for the prediction of organization behavior.

\subsubsection{Change Models}

Change methods can be defined as the actions carried out by managers to deal with change and are grouped under two categories: 1) systematic change methods, and 2) change management methods (Al-Haddad \& Kotnour, 2013).

\section{a. Systematic Change Model (a)}

Systematic change methods involve a certain set of processes and tools to help the management team make a series of start, stop, and continue decisions (Zook, 2007). Several systematic change methods have been proposed in the last 20 years; these methods share many processes such as: scouting and diagnosing the current situation, planning and communicating change and finally implementing and instilling the new changes. Change theories traditionally have promoted incremental process adjustment and infrequent small transitions that are mainly planned and steered by management (Thompson, 1967). More recent change methods have become more systematic, cyclical and integrative, involving higher scales of organizational change (Armenakis \& Bedeian, 1999; Singh \& Shoura, 2006).

\section{b. Change Management Model(b)}

Change management methods are broader and conceptual when compared to systematic change methods. Change management methods tackle change on a large scale and include a range of intervention strategies (Worren et al., 1999). These methods help management to align the change initiative with the overall mission and the organizational strategy by proper planning and creating a vision that involves people in change (Grover, 1999). Change management processes assist in making change is part of the organizational culture. Worren et al.(1999) note that the underlying theory and framework of change management include "principles and tools from sociology, information technology, and strategic change theories" (p. 180).

\subsubsection{Change Outcomes}

Change outcomes can be defined as the consequences of change on the organization. Measuring outcomes can contribute to organizational development and success if the measurement systems are properly developed and employed (Sink \& Tuttle, 1989). Performance measurement help organizations to evaluate the execution of objectives and management of operations by providing the needed information for making decisions (Gunasekaran \& Kobu, 2007; Wouters \& Sportel, 2005). Therefore, for measuring change, one must be clear on the change objectives.

Sink and Tuttle (1989) and Sink et al. (1995) identified seven performance measures: (a) effectiveness, which indicates the accomplishment and outcome; (b) efficiency, which indicates the outcomes relative to the resources used; (c) quality, which indicates the process capability and value; (d) productivity, which indicates the output compared to input; (e) innovation, which indicates the creativity and the ideas put into action; (f) quality of work life, which indicates the workers' conditions; and (g) profitability and "budgetability," indicating the revenue (what was earned compared to what was promised) and the budget versus the actual cost.

Grover (1999) also reports change outcomes in the results of two studies. These outcomes are: (a) improved customer service, (b) improved cycle time, (c) reduced cost, (d) improved quality of product/ services, (e) improved organizational responsiveness, (f) improved employee morale, (g) employees layoffs, and (h) changed organizational structure. Armenakis and Bedeian (1999) argue that typical change outcomes are quality, service, productivity, and risk taking. Neves and Caetano (2009) claim that change outcomes consist of organizational citizenship behaviors, perceived performance, and turnover intentions.

Kaplan and Norton (2001) define the balanced scorecard (BSC) as a tool that supports the alignment between organizational strategy and the operations. The BSC is considered a performance measurement process, which includes the traditional financial measures in addition to qualitative measures such as the organizational mission and the employees and customer's satisfaction. The BSC links intangible and tangible assets by using strategy maps of cause and effect diagrams, and focuses on four main areas: (a) learning and growth, (b) internal, (c) customer, and (d) financial. 
Wouters and Sportel (2005) argue that a performance measurement system "aims to support the implementation and monitoring of strategic initiatives" (p. 1063).This study categorizes change outcomes in terms of: (a) organizational performance after implementing the change, and (b) the change project performance.

\subsection{Empirical Literatures on Factors Affecting Change Management}

Successful management of change is crucial to any organization in order to survive and succeed. For change to be successful, an organization has to overcome all the challenges. The major factors effecting successful change management according to Suresh (2001) are leadership, focus, commitment and resistance. Smith (2002) also conducted a study to determine the major reasons behind organizational change failure and success in different industries across North America. He found that visible and sustained sponsorship, addressing the needs of employees, and strong resources dedication as the main factors affecting change success.

Chepkorir (2013) conducted a study on the factors affecting management of change in the road agencies in Kenya. The study found out that management styles have an effect on management of change within the road agencies. The result of the study also indicated that management of change was affected by factors like creating and sharing an organizational goal, acting as a role model, encouraging creativeness, providing support for employees and allowing employee participation in making job-related decisions. Emmah (2012) also undertook a study on factors influencing management of change in public sector organizations in Kenya, which was guided by a cross sectional descriptive research design with a sample size of 155 respondents. The study found that the major triggers for change management in the organization were external factors. The study also found out that communication, attitude towards change, organizational change and organizations systems were the major factors influencing change in public sector organizations in Kenya.

Key findings from research conducted by Sathe (1985) also evidenced that a strong culture has a greater number of important shared assumptions, which are more widely shared throughout the organization and more clearly prioritized in terms of relative importance. He found that the greater the strength of the culture and the larger the magnitude of the change, the greater the resistance to change.

In Ethiopia, Abebe et al. (2106) has conducted study on challenges and practices of change management in Addis Ababa University Bishoftu College using a mixed research approach. The study found that change strategic plan held in the college working culture improved staffs to build the mutual interest each other than before, improved the practices of sharing ideas and reduced the change resistance occurred at the beginning of change implementation plan. The evaluation of the change management was confined on the paper report on the routine activities. Sense of ownership, national and group interest was going down time to time and passive relationships of leaders towards the worker was increased.

Finally, the conceptual framework presented in figure 2.1 is proposed to examine the determinants of the organizational change implementation success. Establshing the relation between the explanatory variables such as leadership,internal communication,organizational culture, information technology usage and change management method and the dependent variable success of organizational change will enable to identify the magnitude and direction of the effects of factors.

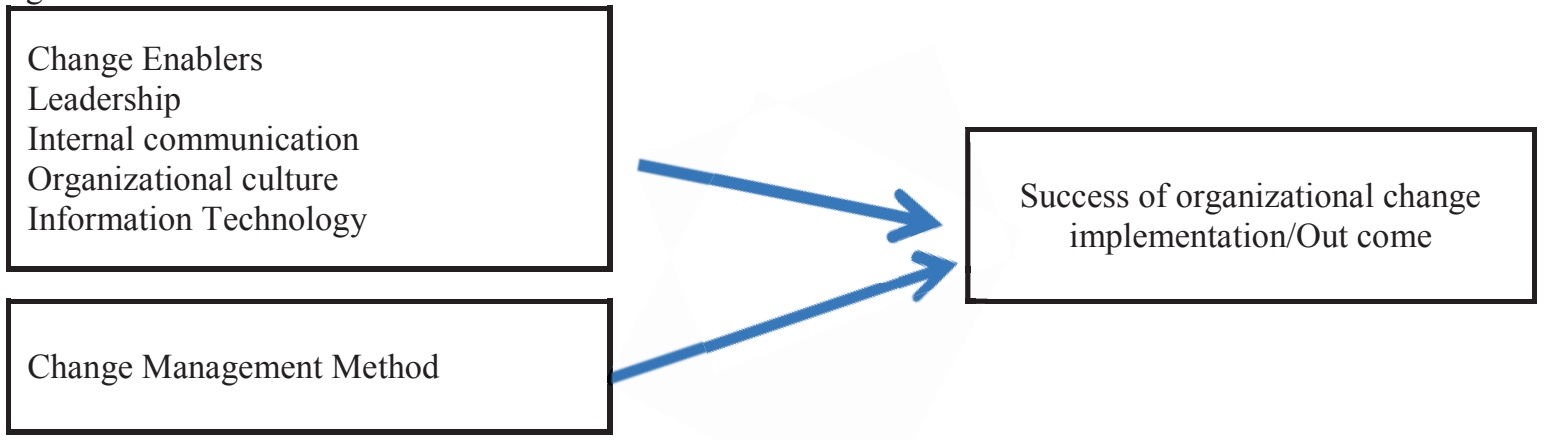

Figure. 2.1. Research Conceptual Model

\section{Research Methodology}

\subsection{Research Approach}

According to Mark et al. (2009) mixing of qualitative and quantitative approaches give the potential to cover each method's weaknesses with strengths from the other method. In this study, both qualitative and quantitative approaches of doing research have been employed, as recommended by Creswell (2009:203-216).

\subsection{Research Design}

The research designs adopt in this research was both descriptive and causal in nature. The descriptive design was 
used to show basic statistics. These statistics would help the reader to understand the general information of the respondent's responses. The study is causal in a sense that the relationship between variables are correlated with the aims of explaining the integrated influence of explanatory variables on an organizational change (Irwin and Scott, 2010).

The time dimension of the study is cross- sectional. Respondents were asked once about issues (Cooper \& Schindler, 2010). The method of data collection was performed through self-administered, which was given to the relevant subjects in person. Perceptive questions were operationalized by using 5-point Likert - scales. This made it possible to process the data quantitatively so that the developed model could be tested with the use of statistical tools.

\subsection{Research Population}

In order to have a clear definition of the population for the research, it was chosen to define population as active employees who are in work by the time of data collection. Therefore, employee who were not in annual leave, on short and long-term training was included in the population. This also made it easier to compare the sample with the population after the primary data is collected. As the evidence from records of Authority shows, there are 170 number of total employees as of April 2021. They are distributed in different directorates as depicted in the following table 3.1 .

Table 3.1: Employee (Population) Distribution by directorates

\begin{tabular}{|l|c|}
\hline Directorates Name & Number of Employee \\
\hline Marketing and Inspection Directorate & 22 \\
\hline Marketing Commitments Tracking Directorate & 23 \\
\hline Communication and information delivery Directorate & 16 \\
\hline Economic Analysis Directorate & 19 \\
\hline Information Technology Directorate & 7 \\
\hline Law enforcement Directorate & 24 \\
\hline Legal Administrative Hearings Directorate & 7 \\
\hline Human Resource Development Directorate & 6 \\
\hline Legal Affairs Monitoring \& Advice Service Directorate & 7 \\
\hline Internal Auditing Directorate & 6 \\
\hline Procurement, finance and property management Directorate & 22 \\
\hline Reform and Good Governance Directorate & 5 \\
\hline Director General's Office & 6 \\
\hline Total & $\mathbf{1 7 0}$ \\
\hline
\end{tabular}

Source: Own construction from Ethiopian Commodity Exchange Authority data set

\subsection{Method of Data Collection}

The study used Self-administered and semi-structured questionnaire for data collection from the employees. Some questions were framed in the form of a Likert scale, ranging from deep disagreement, disagreement, neutral, agree and strongly agree has been used to measure respondents' intermediate level of opinion. Qualitative and quantitative data were collected in such a way as to maintain the validity and reliability of the results of the study.

Open-ended questions were used as a qualitative data collection technique because it can yield a great deal of useful information about facts without the intervention of data collector interest, and perspectives about the facts, feelings, motives, present and past behaviors, standards for behaviors and conscious reasons for actions or feelings.

\subsection{Data Sources}

Both primary and secondary sources of data were used to undertake the study. The major sources of secondary data had been the authority publications, annual and inventory reports, previous studies, and other related literatures. Whereas, the primary data source was the data collected using questionnaires from employees of the Authority.

\subsection{Sample Size Determination}

Since, conducting census survey is manageable in terms of cost, size of population and time, census method was chosen for this study. It was decided that the whole population was to receive a questionnaire, and the one who responded would be part of the final sample. It is challenging to be sure that the final sample actually contains data that is representative for the whole population. One way of confirming the sample is representativeness is utilizing statistical tests to inspect for sampling bias. Several tests for sampling bias and measurement error were 
utilized. For this study purpose, only responded respondents were considered as samples. The sample size, therefore, is adequate to represent the study population

\subsection{Methods of Data Analysis}

Both descriptive and inferential methods were employed to analyze the data. Quantitative data analysis has assisted by SPSS. Among the inferential method, correlation and multiple regression analyses were used. Patterns or content analysis method was used to analyze the qualitative data.

Factor analysis (FA) was also applied to simplify complex data (Taherdoost et al.,2020) and to explore the primary factor structure of the constructs being studied (Hurley et al., 1997; Kim et al., 1978). Factor analysis helps in identifying variables that explain most of the variance observed in a construct (Dillman et al., 2009). It is used to reduce larger sets of variables and summarizes them to composite or indexed factor. This enabled to extract the composite dependent and independent from different constructs. An important rule for factor analysis is that at least three variables are needed to compose a construct; each variable within each construct must have at least three questions to measure it (LandaetaFeo, 2003). Factor analysis is also used to ensure that the intended constructs can be justified, and to prevent that variables that do not represent what they were intended to measure are excluded in the final construct.

The interest of author in this study is measuring and establishing the factors that influence the success of organizational change implementation in the case of Ethiopian Commodity Exchange Authority. The factors affecting the success of organizational change implementation are the independent variables and dependent variable is the success of organizational change implementation, which is measured by proxy variable organizational change outcome. The regression equation was:

$Y=\beta_{0}+\beta_{1} X_{1}+\beta_{2} X_{2}+\beta_{3} X_{3}+\beta_{4} X_{4}+\beta_{5} X_{5}+\varepsilon$

Where, $Y$ is the dependent variable (organizational change implementation success), $\beta_{0}$ is the regression constant. The parameters $\beta_{1}, \beta_{2}, \beta_{3}, \beta_{4}$ and $\beta 5$ are the regression coefficients associated with $X_{1}, X_{2}, X_{3}, X_{4}$, and $X_{5}$ variables, respectively. $X_{1}$ is communication, $X_{2}$ is the leadership, $X_{3}$ is change management method, $X_{4}$ is organizational culture, $\mathrm{X}_{5}$ is system of organization and $\varepsilon$ is the random error component reflecting the difference between the observed and fitted linear relationship.

\section{Results and Discusssion}

\subsection{Invalid Respondents and Missing Data}

In order to ensure quality, all responses were examined in detail after the data collection was completed. The main challenges with the sample was missing data and absence of employee on work with reasons such as annual relief, long term and short term training and field work. Some employee had returned the questionnaire without responding on all or part off questions. With this regard, Table.3.2 summarizes the removal of invalid respondents:

Table.3.2: Deleted Respondents

\begin{tabular}{|l|l|l|}
\hline No. & Problems & invalid responses \\
\hline 1 & missing data in the questionnaire & 2 \\
\hline 2 & individuals on annual relief & 3 \\
\hline 3 & long term and short term training and field work & 8 \\
\hline & Total deleted respondents & 13 \\
\hline
\end{tabular}

\subsection{Disagreggation of the Respondents by Directorates}

The final sample after deletions of the missed respondents consisted of 157 employees. The distribution of employees by the directorates for this final sample was depicted in table 3.3. 
Table.3.3: Final sample Distribution by directorates

\begin{tabular}{|l|l|c|c|}
\hline No. & Directorates Name & $\begin{array}{c}\text { Number of } \\
\text { Employee }\end{array}$ & $\begin{array}{c}\text { \%of employee in } \\
\text { final sample }\end{array}$ \\
\hline 1 & Marketing and Inspection Directorate & 21 & 13.38 \\
\hline 2 & Marketing Commitments Tracking Directorate & 19 & 12.10 \\
\hline 3 & Communication and information delivery Directorate & 17 & 10.83 \\
\hline 4 & Economic Analysis Directorate & 19 & 12.10 \\
\hline 5 & Information Technology Directorate & 7 & 4.46 \\
\hline 6 & Law enforcement Directorate & 18 & 11.46 \\
\hline 7 & Legal Administrative Hearings Directorate & 8 & 5.10 \\
\hline 8 & Human Resource Development Directorate & 6 & 3.82 \\
\hline 9 & Legal Affairs Monitoring \& Advice Service Directorate & 8 & 5.10 \\
\hline 10 & Internal Auditing Directorate & 6 & 3.82 \\
\hline 11 & Procurement, finance and property management Directorate & 20 & 12.74 \\
\hline 12 & Reform and Good Governance Directorate & 5 & 3.18 \\
\hline 13 & General Director Office & 3 & 1.91 \\
\hline & Totals & $\mathbf{1 5 7}$ & $\mathbf{1 0 0 \%}$ \\
\hline
\end{tabular}

\subsection{Sampling bias test}

A common test has applied for detecting the representativeness of sample to the population was used. The test is mostly constrained by the information that is available about the population and sample. In this case, numbers regarding employee were reliable for both the sample and the population..

The Equality of variance between the groups was tested using the variance comparison test. Since, $\mathrm{p}$-value, which is equal to 0.699 , is greater than the conventional significance level 0.01 or 0.05 , the null hypothesis under which the equality of variance between sample and population stated was not rejected. The t-tests result in the table also shows that there is no statistically significant difference between the mean of employee included in final sample and the population. From this, one can understand that there is no statistically significant difference between the sample and population.

Table 3.4: Sampling bias test result

\begin{tabular}{|c|c|c|c|c|c|c|c|c|c|c|}
\hline \multirow{2}{*}{$\begin{array}{c}\text { Test } \\
\text { Variable }\end{array}$} & \multicolumn{4}{|c|}{ Group Statistics } & \multicolumn{3}{|c|}{ Variance- comparison test } & \multicolumn{3}{|c|}{$\begin{array}{c}\text { t-test for equality } \\
\text { of means }\end{array}$} \\
\hline & Cases & $\mathbf{N}$ & Mean & Std.dev & Assumption & chi2 & Sig & t & df & $\begin{array}{l}\operatorname{sig}(2- \\
\text { tailed })\end{array}$ \\
\hline \multirow{2}{*}{$\begin{array}{l}\text { Employee in } \\
\text { Directorate }\end{array}$} & population & 170 & 12.08 & 6.85 & $\begin{array}{l}\text { Equal } \\
\text { variance } \\
\text { assumed }\end{array}$ & \multirow{2}{*}{9.043} & \multirow{2}{*}{0.7} & \multirow{2}{*}{0.5} & \multirow{2}{*}{12} & \multirow{2}{*}{0.695} \\
\hline & Sample & 157 & 13.08 & 7.89 & $\begin{array}{l}\text { Equal } \\
\text { variance } \\
\text { not assumed }\end{array}$ & & & & & \\
\hline
\end{tabular}

\subsection{Response Rate}

In a population survey of 170, 157 questionnaires were returned correctly filled representing a response rate of $92.35 \%$ as shown in Table.4.1. According to Kothari (2004) a 50\% response rate is adequate, $60 \%$ good and above $70 \%$ rated very good. Therefore, that, this response rate is categorized as very good. As we considered 157 as sample size, then turn-out would be $100 \%$

Table 4.1: Response Rate

\begin{tabular}{||l|c|c|}
\hline Questionnaires & Frequency & Percentage \\
\hline Returned & 157 & 92.35 \\
\hline Non returned & 13 & 7.65 \\
\hline Total & $\mathbf{1 7 0}$ & $\mathbf{1 0 0}$ \\
\hline
\end{tabular}

\subsection{Demographic Characteristics of Respondents}

\subsubsection{Gender of Employee}

From the total respondents 122 respondents representing $77.7 \%$ of respondents were male while the remaining $22.3 \%$ were female respondents. This figure shows that there was more male's employee than female's employee in the Authority. 
Table 4.2: Frequency Distribution of Respondents by Gender

\begin{tabular}{|ll|c|c|c|c|}
\hline & & Frequency & Percent & Valid Percent & Cumulative Percent \\
\hline \multirow{3}{*}{ Valid } & Male & 122 & 77.7 & 77.7 & 77.7 \\
& Female & 35 & 22.3 & 22.3 & 100.0 \\
& Total & 157 & 100.0 & 100.0 & \\
\hline
\end{tabular}

\subsubsection{Age of the Respondents}

As shown in the Table 4.3, 37.6\% of respondents from the total respondents have age greater than 30 and less than 41 , followed by $33.1 \%$ of respondents with age greater than 20 and less than 31-year-old. Likewise, from the remaining $22.9 \%$ had greater than 40 years and less than 51 -year-old while only $6.4 \%$ had greater than 50 years. From this figure, we can understand that $70.7 \%$ of respondents from the total respondents have age within the age range of $20-41$, which shows that the majority of the employee in the Authority is still young and energetic.

Table 4.3: Frequency Distribution of Respondent's by Age

\begin{tabular}{|l|l|c|c|}
\hline \multicolumn{5}{|c|}{ V } & Frequency & Percent \\
\hline \multirow{4}{*}{ Valid } & Age of employee greater than 20 and less than 31 & 52 & 33.1 \\
\cline { 2 - 4 } & Age of employee greater than 30 and less 41 & 59 & 37.6 \\
\cline { 2 - 4 } & Age of employee greater than 40 and less than 51 & 36 & 22.9 \\
\cline { 2 - 4 } & Total & 10 & 6.4 \\
\hline
\end{tabular}

\subsubsection{Educational Level of Employees}

As revealed in the Table 4.4, 59.2\%, 22.9\% and $17.8 \%$ of respondents are employees with educational level of undergraduate, diploma and graduate, respectively. This implies that all most employee of the authority have satisfactory educational level.

Table 4.4: Frequency Distribution of Respondent's by Educational Level

\begin{tabular}{|ll|c|c|c|c|}
\hline & Frequency & Percent & Valid Percent & $\begin{array}{c}\text { Cumulative } \\
\text { Percent }\end{array}$ \\
\hline \multirow{4}{*}{ Valid } & & 28 & 17.8 & 17.8 & 17.8 \\
& Graduate & 93 & 59.2 & 59.2 & 77.1 \\
& Under graduate & 36 & 22.9 & 22.9 & 100.0 \\
& Diploma & 157 & 100.0 & 100.0 & \\
\hline
\end{tabular}

\subsubsection{Work Experience of Respondents}

The result shown in the Table 4.5 indicates that $17.8 \%$ of employee have less than three years' experience while $46.5 \%$ of the employee have experience between 3 and 7 years. The remaining $35.7 \%$ of the respondents have greater than 7 years' of experience. More than $82.2 \%$ of the employee from the total employee of the authority has stayed more than three years. This implies that the turnover of the employee in the authority is not a serious problem.

Table 4.5: Frequency Distribution of Respondent's Work Experience

\begin{tabular}{|c|c|c|c|c|c|}
\hline & & Frequency & Percent & Valid Percent & $\begin{array}{c}\text { Cumulative } \\
\text { Percent }\end{array}$ \\
\hline Valid & $\begin{array}{l}\text { Less than three years } \\
\text { between three and } 7 \text { years } \\
\text { greater } 7 \text { years } \\
\text { Total }\end{array}$ & $\begin{array}{c}28 \\
73 \\
56 \\
157\end{array}$ & $\begin{array}{c}17.8 \\
46.5 \\
35.7 \\
100.0\end{array}$ & $\begin{array}{c}17.8 \\
46.5 \\
35.7 \\
100.0\end{array}$ & $\begin{array}{c}17.8 \\
64.3 \\
100.0\end{array}$ \\
\hline
\end{tabular}

\subsection{Reliability Test of Composed Factor Constructs}

To ensure a good factor analysis, variables should be correlated to some extent, but not be correlated perfectly (Field, 2005). The correlation matrix between the variables was therefore scanned in order to see if there was any correlations coefficient above 0.9 as presented in appendix.A.none of these was found. Thus, the requirement was satisfied. As the result, no variable suggested to be eliminated from the analysis at this stage.

One way of testing the consistency between the items in each factor is through the Cronbach's alpha test. The Cronbach's alpha is based on the average inter-item correlation. A scale with a Cronbach's alpha higher than 0.7 is required in order to create a reliable construct of multiple variables (Pallant , 2005).

Accordingly, six variables that were supposed to form the construct of the independent variable leadership were tested and the Cronbach's alpha for all six variables was .860, which is a good score. Likewise, analysis was done to know how much the reliability would increase/decrease if any of the items are deleted as indicated in appendex. If the variable measuring lack of proper knowledge by top leaders removed, reliability would 
increase from 0.86 to 0.882 . It was therefore, decided to exclude the lack of proper knowledge by top leader is variable and only keep five variables in the final construct.

Likewise, as shown in table 4.6, the Cronbach's alpha for all six variables which used to construct internal communication composite variable was 0.817 , which is a good score. As indicated in Appendix B, omitting the variable employee training would increase the reliability from 0.817 to 0.831 . It was therefore, decided to exclude that there is adequate training to enable employees cope with the change implementation variable and the remaining five variables were used to construct the internal communication composite factor.

As shown in table 4.6, the reliability test of all variables that were used to construct the organizational culture composite index has Cronbach's alpha of .761, which is a good score. And as presented in appendex B , If the variable measuring employee resistance towards change removed, the reliability of the remaining variable used to construct the organizational culture composite factor would increase from 0.761 to 0.805 . Therefore, it was decided to exclude employee's resistance towards change variable and the remaining three variables wre used to construct the variable. Similarly, the Cronbach's alpha which is 824 for all five variables that were supposed to form the construct of the independent variable information communication technology index was looks a good score. And the reliability test of the variables used for the final construction the communication technology index shows all variable are reliable for the construction.

As shown in the table 4.6, the Cronbach's alpha which is 0.897 for all the eight variables that were selected to form the construct of the dependent variable change success index is signaling a good score. As seen in appendix B, the Cronbach's alpha for each of the eight factors was less than or equal to the Cronbach's alpha for all eight variables i.e.0.897. Thus, no factor is excluded from final construct of the variable change success index.

Finally, the five variables that were supposed to form the construct of the independent variable change management method composite factor has Cronbach's alpha of 0.774 , which is a good score. The reliability test of the items shows that If we remove the variable change projects alignement with the overall mission of organization the reliability of the remaining four variable would increase and the Cronbach's Alpha for each factors will become greater than 0.7 as shown in the appendix B. It was therefore, decided to exclude the change projects alignenment with the overall mission of organization to construct organizational change management method compsite factor.

Table 4.6: Reliability Test Statistics for the Composite Factors Construct

\begin{tabular}{|l|l|}
\hline \multicolumn{2}{|c|}{ Reliability Test Statistics for Leadership Index Construct } \\
\hline Cronbach's Alpha & No. of Items \\
\hline 0.86 & 6 \\
\hline Cronbach's Alpha & N of Items \\
\hline 0.817 & 6 \\
\hline \multicolumn{2}{|c|}{ Reliability Statistics for Organizational Culture } \\
\hline Cronbach's Alpha & N of Items \\
\hline 0.761 & 4 \\
\hline \multicolumn{2}{|c|}{ Reliability Statistics for Information Communication Technology Index } \\
\hline Cronbach's Alpha & N of Items \\
\hline 0.824 & 5 \\
\hline \multicolumn{2}{|c|}{ Reliability Statistics for Change Success Construct } \\
\hline Cronbach's Alpha & N of Items \\
\hline 0.897 & 8 \\
\hline Rronbach's Alpha & Neliability Statistics for Change Management Method \\
\hline 0.774 & 5 \\
\hline
\end{tabular}

\section{Qualitative Analysis for the open ended Questions}

Open ended questions were posed to the respondents with the intention of identifying the challenges experienced in the change implementation process in the authority. When their responses categorized in major parts of challenges, the incompatibility of the ICT with mission, ineffective internal communication in some instances, weak work culture, weakness in implementation and evaluation of change projects, absence of incentives for 
employee, shortage of chance for educations for employee, shortage of vehicles for field based work and weak engagement of few leaders and employees for change were the main challenges. Likewise, lack of adjustment of the employees with newly introduced systems and instruments on the due process of change implementation. To bring these and other related challenges, which were stated by the respondents to a broader term, the incompatibility of the ICT with mission, shortage of charismatic leader and presence of gaps in aligning the change management methods with the specific context of the authority.

\subsection{Preliminary Tests for Regression Analysis}

\subsubsection{Correlations and Multicollinearity}

Before presenting the regression models, one should inspect if there are excessive correlations between the variables in the model. The correlation matrix can have scanned as a preliminary look for multicollinearity. To avoid multicollinearity in the sample, there should be no substantial correlations $(R>0.8)$ between the predictors (Field, 2005). The correlation matrix in Appendix. A Shows that, there are no variables that have excessive correlations, which is greater than 0.8 between them. Although regression and correlation must be treated as different things, one can scan the correlation matrix in order to see potential relations that may also show up in the regression models. In addition to checking the correlation matrix, it is important to check the variance inflation factor (VIF). VIF indicates whether a predictor has a strong linear relationship with other predictors in the model. The largest VIF should not be greater than 10, and the average VIF should not be much higher than one (Field, 2005). The VIF for each predictors and the average are summarized in Table 4.27 below. All VIF values are well below 10 and the average is close to one. One can therefore conclude that there are no signs of excessive multicollinearity within the model.

Table.4.27. Variance inflation factor of predictors

\begin{tabular}{|l|c|}
\hline Predictors & VIF \\
\hline & 1.194 \\
leadership composite index & 1.098 \\
Internal communication index & 1.093 \\
organizational culture index & 1.054 \\
Information technology index & 1.244 \\
\hline
\end{tabular}

a. Dependent Variable: Organizational change success index

Source: Own survey, 2021

\subsubsection{Homoscedasticity/Heteroscedasticity}

Regression model should be assumed to have a constant variance of residuals; one has to check if this assumption met. One way of doing this is to look at the plot in Figure below, which is a scatter plot of standardized residuals against standardized predicted values. The graph should show a random array of dots that are evenly dispersed around zero. If, for example the graph funnels out, there are chances that there is heteroscedasticity in the sample. In addition, if the graph plots any sort of curve, there are chances that the data have broken the assumption of linearity. In this case, however, the graph shows a random dispersion around zero, and one can conclude that the assumption of homoscedasticity has been met.

\section{Partial Regression Plot}

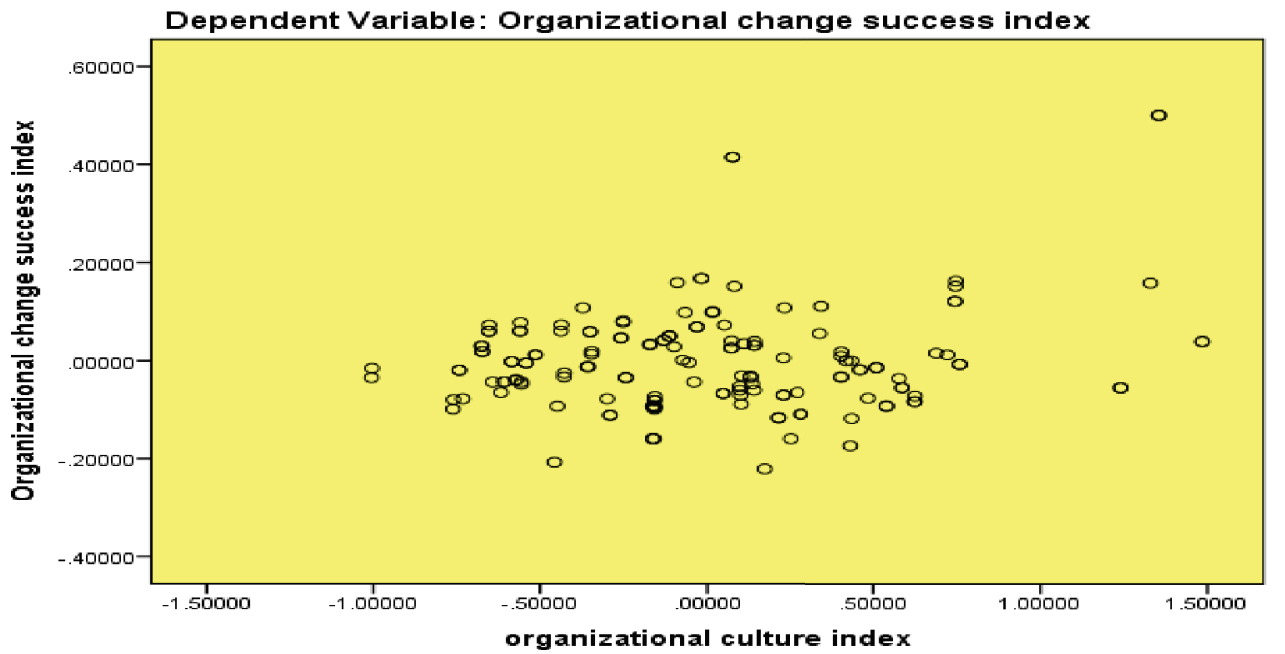

Figure .4.1: scatter plot of a standardized residuals against standardized predicted values. 
It is also important to check the normality of residuals. This can be done by looking at the histogram (left) and normal probability plot (right) in Figure below. One can see from the histogram that the distribution is rather normal. The mean is also very close to zero.

Histogram

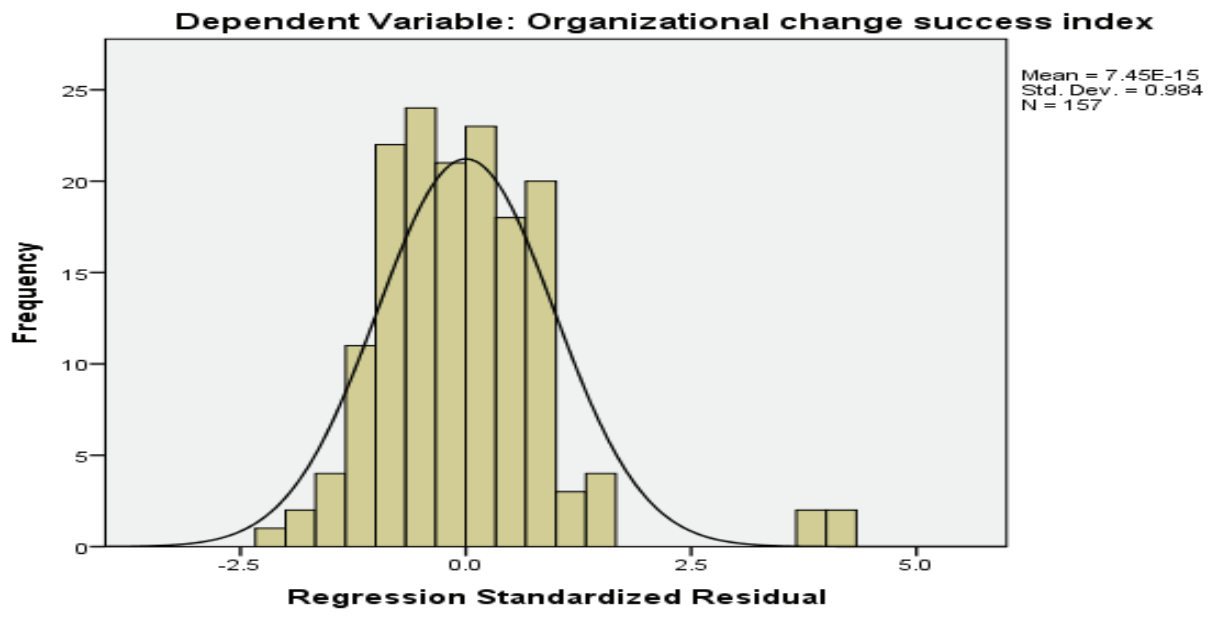

Figure. 4.2: Normality Test of Regression Residual

The normal probability plot portrayed in figure 4.3 also shows there are deviations from normality. The points are the observed residuals, while the line represents the normal distribution. If all dots had been straight on the line, it would have meant that the residuals had been perfectly normally distributed. In this case, the plot seems to be close to normal since most of the data point tends to lie on a straight line.

\section{Normal P-P Plot of Regression Standardized Residual}

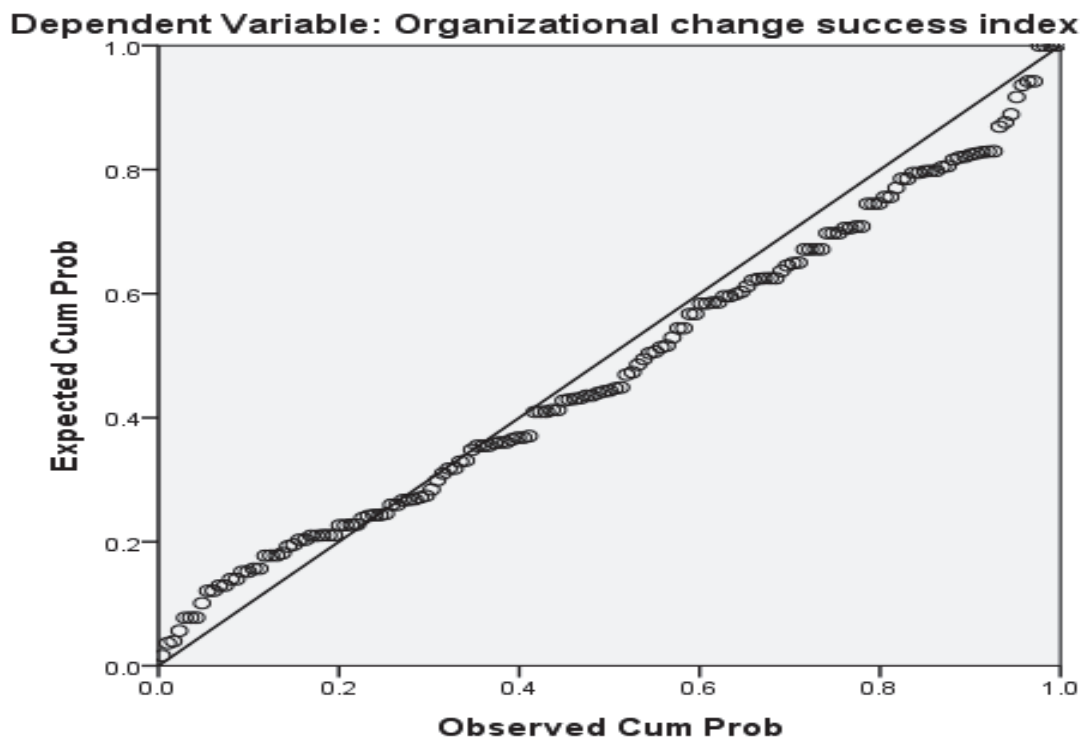

Figure .4.3: Normal Probability plot

Adjusted $\mathrm{R}$ squared is coefficient of determination, which tells us the variation in the dependent variable due to changes in the independent variable. Based on this sense, $R$-square $\left(R^{2}\right)=0.96$ shown in the table below indicates that $96 \%$ of the variation (change) in organizational change implementation success is attributed to the effect of leadership composite factor, internal communication composite index, organizational culture composite index.

Table.4.28: Regression Model Summary

\begin{tabular}{|c|c|c|c|c|}
\hline Model & R & R Square & Adjusted R Square & Std. Error of the Estimate \\
\hline 1 & $.980^{\mathrm{a}}$ & .961 & .960 & .10694052 \\
\hline
\end{tabular}

Source: constructed from survey data,2019

4.7.3. The Model Adequacy Test

The pro (F-statistics) $=0.00$ presented in the table below, which is less than the conventional level of significance such as 0.01 or 0.05 . Thus, we reject the null hypothesis and can conclude that at least one of the explanatory 
(independent) variables is significant, that is there is a significant linear relationship between the dependent variable Organizational change implementation success index and independent variables such as Organizational change management method index, Information technology index, Internal communication index, organizational culture index and leadership composite index.

Table .4.29: Analysis of Variance (ANOVA)

\begin{tabular}{|c|c|c|c|c|c|}
\hline Model & Sum of Squares & Df & Mean Square & $\mathrm{F}$ & Sig. \\
\hline $\begin{array}{c}\text { Regression } \\
\text { Residual } \\
\text { Total }\end{array}$ & $\begin{array}{c}42.342 \\
1.727 \\
44.069\end{array}$ & $\begin{array}{c}5 \\
151 \\
156\end{array}$ & $\begin{array}{c}8.468 \\
.011\end{array}$ & 740.483 & $.000^{\mathrm{b}}$ \\
\hline
\end{tabular}

Source: Computed from own survey data, 2019

\subsection{Discussion of the Regression Model Result}

As shown in the regression estimation output Table 4.30 below, the variable such as leadership composite index, internal communication index, organizational culture index and organizational change management method index has positive sign coefficients as expected. Except organizational culture index, which is significant at 5\% level of significance, the other remains are statistically significant at 5\% level of significance. Likewise, since pvalue for information communication technology, which is 0.274 , is greater than the conventional level of statistical significance 0.01 0r 0.05 ; it is not statistical significant. Thus, except information communication technology, those explanatory variables with positive and statistically significant coefficients have direct linear relationship with the dependent variable. The major respondent's response for the open question posed to assess the challenges experienced in the change implementation is incompatibility information technology installed with the organization missions. This might be the reason for the insignificance of the role of information communication technology on the success of organizational change implementation.

To be more specific, a one unit increase in leadership composite index, internal communication index, organizational culture index, and organizational change management method index will brings (results) 0.958, $0.61,0.42$ and 0.59 unit increment in Organizational change implementation success index holding other factors constant. This statistically significant effect of organizational culture on the dependent variable change implementation success has similarity with finding of Agili and Okibo (2015) studies conducted in selected public universities in Kenya. Likewise, the finding regarding the internal communication has similarity with the finding of study conducted by Beatrice (2017) in Kenya on topic factors affecting change management in state corporations. He found that communication by top leadership influenced change implementation success in the organization largely and some failure in internal communication had led to failure of implementation of change management largely. This implies that communication is key, during the change implementation process for it to be a success. In similar fashion, the finding regarding the influence of leadership on the change implementation success shown above has similarity with finding of study undertaken by Khan et al.(2016) on role of leadership on organizational change in Pakistan. Finally, they found that a leader with its competencies i.e. "Visionary", "democratic" and "transformational" along with "Innovative Approach" could ascertain more effective organizational change implementation with success. In addition, Beatrice (2017) conducted a study in Kenya on a topic factors affecting change management in state corporations. The result highlited that highly skilled leadership has most desirable positive effect on organizational change implementation success.

Table.4.30: Multiple Regression Model SPSS Out put

\begin{tabular}{|c|c|c|c|c|c|}
\hline \multirow[t]{2}{*}{ Model } & \multicolumn{2}{|c|}{$\begin{array}{l}\text { Unstandardized } \\
\text { Coefficients }\end{array}$} & \multirow{2}{*}{$\begin{array}{c}\begin{array}{c}\text { Standardized } \\
\text { Coefficients }\end{array} \\
\text { Beta }\end{array}$} & \multirow[t]{2}{*}{$\mathrm{t}$} & \multirow[t]{2}{*}{ Sig. } \\
\hline & $\mathrm{B}$ & Std. Error & & & \\
\hline (Constant) & -.049 & .025 & & -1.911 & .058 \\
\hline leadership composite index & .927 & .017 & .958 & 54.440 & .000 \\
\hline Internal communication index & .059 & .016 & .061 & 3.610 & .000 \\
\hline organizational culture index & .042 & .017 & .042 & 2.510 & .013 \\
\hline Information technology index & -.015 & .014 & -.018 & -1.097 & .274 \\
\hline $\begin{array}{l}\text { Organizational change management method } \\
\text { index }\end{array}$ & .058 & .017 & .059 & 3.311 & .001 \\
\hline
\end{tabular}

Source: Computed from own survey data, 2019

\section{Conclusion and Recommendations}

\subsection{Conclusion}

The main objective of the study was to examine the factors influencing success of organizational change 
implementation in the case of Ethiopian commodity exchange authority.

In light of the above objective, the result of the study indicates that organizational change management method, internal communication, leadership and organizational culture have positive and significant role in the success of organizational change implementation in the authority. As the result, one can deduce that choosing an appropriate organizational change management method that fits the goals and objective of an organization is very crucial in change implementation success. Similarly, we can conclude that good internal communication positively influences organizational change implementation as employees are prepared for the changes. The study also concludes that the effective leadership of authority has significant role to play for successful organizational change implementation. Leaders, usually control resources such as people, budgets, and equipment, and thus have the authority to make decisions and to commit adequate resources in orders to ensure successful change management process. In similar ways, organizational culture influences the success of change implementation as shown in the regression analysis result of this study. This implies that institution's culture is found to be a powerful driving force in implementation of change when consistency of the culture gets well with the change management strategies. Evidence also suggests that organization members are more inclined to embrace change when the organization's culture is aligned with the mission and goals of the organization.

\subsection{Recommendations}

Since internal communication is found to influence the success of change implementation significantly, the study recommends that establishment of proper internal communication channels has to be enhanced in future for effective implementation of change practices in the authority. There is a need to develop internal communication channels to promote change implementation processes. This will resolve failures in internal communication that have sometimes led to failure of change implementation and leadership, which influences in return success of change implementation. Further, this will enable effective communication regarding change implementation within the department.

As stated in the finding of this study, organization culture has positive and significant influence on the success of change implementation in the authority. Thus, institution's structure is recommended to be well aligned to provide overall framework for strategy implementation, the institution's culture should also recommend to be consistent with the change management strategy. The institution's culture should also be enhanced as a powerful driving force in implementation of change management and the firm's mission, strategy and key long-term objectives are strongly influenced by the personal goals and values of its management. Authority is also recommended to work on employees to have positive attitudes toward organizational change.

Effective leadership has positive significant effect on success of organizational change implementation in the authority as stated in the finding of this study. So that the top leadership has expected to allocate and provide more resources, both financial and human, to support change implementation. Besides provision of resources, leadership has to promote enhancing teamwork, shares organizational goals with employees and allows employees participation in job related decision making that would support the organizational change implementation process.

Change management method has also positive and significant effect on the success of organizational change implementation as shown in the finding of this study. So that the factors, which were used to construct the change management method are recommended to be effectively implemented. Accordingly, it is recommended that the change that needed to be addressed has to be clearly identified and the situation is needed be analyzed. Likewise, it is also found that the organization's mission, strategy, and key long-term objectives are influenced by organizational goals, the change projects have to be aligned with the overall missions.

In the pursuit of conducting this study, the researcher initially experienced challenges of getting information/data from the key informant respondents who were the management staff through semi-structured interview. Accessing the management staff of authority was difficult as they were busy and there were times difficult to fit in their busy schedules. However, the researcher has tried to mitigate the challenge of access to the respondents by providing them with a structured question to respond at their convenient time. Whatever effort had been used exhaustively to mitigate the validity and reliability of the data collected using structured question, the data is not triangulated using the interview method. As a result, the conclusions, which are made based on this research might mislead to some extent.

This study looked at factors influencing the success of change implementation in Ethiopian commodity exchange authority. So that, as far as this study was concerned with factors influencing the success of change implementation in the case of Ethiopia commodity exchange authority, the finding may not be conclusive to tell whether this factors influence the success of change management in other public sectors. In this regard, the study recommends a replica study to be conducted in other public organizations for comparison of results. Thus, future studies should further establish other factors that affect success of change implementation in organizations, other than the ones identified by this study. 


\section{Acknowledgements}

I would like to express my greatest gratitude to the Ethiopian Commodity Exchange Authority staff for the quality data provision and my wife for her enduring patience and endless encouragement.

\section{Reference}

Abebe, G. D., Development, O., \& Ababa, A. (2016). Challenges and practices of change Management: The case of Addis Ababa University Bishoftu Campus.

Agili, J., \& Okibo, W. (2015). Factors Influencing Implementation of Change in Selected Public Universities in Kenya. International Journal of Economics, Commerce and Management, 3(5), 1201-1217

Al-Haddad, S., \&Kotnour, T. (2013). Preliminary framework for aligning organizational change. Proceedings of the 2013 Industrial and Systems Engineering Research Conference A. Krishnamurthy and W.K.V. Chan, Eds. Puerto Rico.

Anderson, D., \& Ackerman Anderson, L. S. (2001). Beyond change management: Advanced strategies for today's transformational leaders [electronic resource]. San Francisco, CA: Jossey-Bass/Pfeiffer.

Ansoff, I. \& McDonnell, E. (1990). Implanting strategic management. New York: Prentice Hall.

Ansoff, H. I. (1999). Implanting strategic management. London, UK: Prentice Hall.

Armenakis, A. A., \& Bedeian, A. G. (1999). Organizational change: A review of theory and research in the 1990s. Journal of Management, 25(3), 293-315.187

Bamford, D. R., \& Forrester, P. L. (2003). Managing planned and emergent change within an operations management environment. International Journal ofOperations\& Production Management, 23(5), 546564.188

Beatrice, W. (2017). Factors affecting change management in state corporations in Kenya. A research project submitted in partial fulfillment of the requirements for award of master of business administration degree, school of business, university of Nairobi.

Beck, Don Edward (1966). The Rhetoric of Conflict and Compromise: A Study in Civil War Causation (PhD). Norman, OK: University of Oklahoma. OCLC 3401047.

Bennis, W., and Nanus, Burt Leaders. (New York: Harper \& Row, 1987).

Bridges, W. (2003). Managing transitions: Making the most of change (2nd ed., updated and expanded. ed.). Cambridge, MA: Da Capo.

Burnes, B. (2004). Kurt lewin and the planned approach to change: A re-appraisal. Journal of Management Studies, 41(6), 977-1002.

Burnes, B., \& Jackson, P. (2011). Success and failure in organizational change: An exploration of the role of values. Journal of Change Management, 11(2), 133-162.

Butcher, D., Atkinson, S. (2001). "Stealth, secrecy and subversion: the language of change", Journal o f Organizational Change Management, 14(6), 554-69

By, R. T. (2005). Organizational change management: A critical review. Journal of Change Management, 5(4), $369-380$

Chepkorir, J. (2013). Factors Affecting Management of Change in the Road Agencies in Kenya. Unpublished Master Research Project. United of Nairobi, Kenya.

Chia, R., King, I. (2001). "The language of organization theory", in Westwood, R., Linstead, S. (Eds), The Language of Organization, Sage, London, .71

Creswell J. W. (2009). Research Design: Qualitative, Quantitative, and Mixed Methods Approaches. 3rd edition. Landon. Sega publication.

Cooper, D. R., \& Schindler, P. S. (2010). Business Research Methods. New York: McGraw-Hill/Irwin

Conner, D. (1998). Leading at the edge of chaos: How to create the nimble organization. New York: John Wiley.

Davidsson, P. (2005). Paul D. Reynolds: Entrepreneurship research innovator, coordinator, and disseminator. Small Business Economics, 24(4), 351-358. https://doi.org/10.1007/s11187-005-0690-z

Dillman, D. A., Smyth, J. D., \& Christian, L. M. (2009). Internet, mail, and mixed-mode surveys: The tailored design method. Hoboken, NJ: John Wiley \& Sons Inc.

Dunphy, D., \&Stace, D. (1993). The strategic management of corporate change. Human Relations, 46(8), $905-$ 920.

Emmah, S. A. (2012). Factors influencing management of change in public sector organizations in Kenya by Emmah S. A bosire a research project submitted in partial fulfillment of the requirement for the award of the degree of Masters in business administration, school of business, university of Nairobi.

Field, A. (2005). Discovering statistics using SPSS (2nd ed.). London: Sage Publications.

Gioia, D. A., Patvardhan, S. D., Hamilton, A. L., \& Corley, K. G. (2013). Organizational identity formation and change. Academy of Management Annals, 7(1), 123-193. https://doi.org/10.1080/19416520.2013.762225

Goleman, D. (2000). Leadership that gets results. Harvard Business Review, 78(2), 78-90.

Griffith-Cooper, B., \& King, K. (2007). The partnership between project management and organizational change: 
Integrating change management with change leadership. Performance Improvement, 46(1), 14-20.

Grover, V. (1999). From business reengineering to business process change management: A longitudinal study of trends. IEEE Transactions on Engineering Management, 46(1), 36.A guide to the project management body of knowledge (PMBOK guide) (2004).

Gunasekaran, A., \& Kobu, B. (2007). Performance measures and metrics in logistics and supply chain management: A review of recent literature (1995-2004) for research and applications. International Journal of Production Research, 45(12), 2819-2840.

Haidar, E. (2006). Leadership and management of change. Journal of Community Nursing, 20(4), 13.

Haider, H., Frensch, P. (1999). "Information reduction during skill acquisition: the influence of task instruction", Journal of Experimental Psychology Alied, 5(2), 129-51.

Hailey, V. H., \&Balogun, J. (2002). Devising context sensitive approaches to change: The example of Glaxo well come. Long Range Planning: International Journal of Strategic Management, 35(2), 153-178.

Hamel, G. (2000). Leading the revolution. Boston, MA: Harvard Business School Press.

Hayes, B.E. (2007). Measuring customer satisfaction: Survey design, use and statistical analysis methods (2nd Ed). Milwaukee, WI: ASQ Quality Press

Hotek, D. R., \& White, M. R. (1999). An overview of performance technology. Journal of Technology Studies, 25(1), 43-50.

Hurley, A. E., Scandura, T. A., Schriesheim, C. A., Brannick, M. T., Seers, A., Vandenberg, R. J., \& Williams, L. J. (1997). Exploratory and confirmatory factor analysis: Guidelines, issues, and alternatives. Journal of Organizational Behavior, (6), 667.

Igbaria, M. (1993). "User acceptance of microcomputer technology. An empirical test", International Journal of Management Science, 21 (1), 73-90.

Irwin, D., \& Scott, J. M. (2010). Barriers Faced by SMEs in Raising Bank Finance. International Journal of Entrepreneurial Behavior and Research. 16(3), 245-259.

Johnson,G. and Scholes K., (2002), Exploring Corporate Strategy, 6th Edition, Prentice Hall

Kanter, R. M., Stein, B., \& Jick, T. (1992). The challenge of organizational change: How companies experience it and leaders guide it. New York: Free Press; Toronto: Maxwell Macmillan Canada; New York: Maxwell Macmillan International.

Kanter, R. M. "The Enduring Skills of Change Leaders." Leader to Leader 13 (summer 1999). (Reprinted in Ivey Business Journal, May-June 2000, pp. 1-6.)

Kaplan, R. S., \& Norton, D. P. (2001). The balanced scorecard- Measures that drive performance. Harvard Business Review, 70(1), 71-79

Keller, S \& Aiken, C. (2000). The Inconvenient Truth About Change Management -Why it isn't working and what to do about it.

Kenny, J. (2006). Strategy and the learning organization: A maturity model for the formation of strategy. Learning Organization, 13(4), 353-368.

Khan, U., Khan, A., Khan, S., \& Fatima, S. (2016). The Role of Leadership on Organizational Change, (11), 8895

Kim, J., Mueller, C. W., \& Mueller, C. W. (1978). Factor analysis: Statistical methods and practical issues. Beverly Hills, CA: Sage Publications.

Kothari, C. R. (2004): Research Methodology, New Delhi. New Age International Publishers

Kotnour, T. (2011). An emerging theory of enterprise transformations. Journal of Enterprise Transformation, $1(1), 48-70$.

Kotter, J. P. (1996). Leading change. Boston, MA: Harvard Business School Press. Kotter, J. P., \& Schlesinger, L. A. (2008). Choosing strategies for change. Harvard Business Review, 86(7), 130-139.

Kotter, J. P. \& Schlesinger, L. A. (2008). Choosing Strategies for Change, Harvard Business Review, 86 (7-8)

Kotter, J., \& Rathgeber, H. (2006). The penguin principle. How change becomes a success. Droemer, Munich.

Kouzes, J. M., \& Posner, B. Z. (1995). The leadership challenge: How to keep getting extraordinary things done in organizations. San Francisco, CA: Jossey-Bass.

LandaetaFeo, R. E. (2003). Knowledge management across projects 2003. Lannes, W. J. (2001). What is engineering management? IEEE Transactions on Engineering Management, 48(1), 107.

Lewis, L. K., Schmisseur, A. M., Stephens, K. K., \& Wier, K. (2006). Advice on communicating during organizational change. Journal of Business Communication, Volume 43, No., 113-137.

Likert, R. (1932). A technique for the measurement of attitudes. Archives of Psychology, 22140

Madanchian, M., Hussein, N., Noordin, F., \& Taherdoost, H. (2017). Leadership Effectiveness Measurement and Its Effect on Organization Outcomes. Procedia Engineering, 181, 1043-1048. https://doi.org/10.1016/j.proeng.2017.02.505

Mark S, Philip L and Adrian T. (2009). Research Methods for Business Students. Fifth edition, FT Prentice Hall Meyer, C. B., \& Stensaker, I. G. (2006). Developing capacity for change. Journal of Change Management, 6(2), 
217-231.

Michel, J. S., Clark, M. A., Michel, J. S., Clark, M. A., \& Beiler, A. A. (2016). Work-life conflict and its effects Work - life conflict and its effects. August, 58-76.

Min, H.,Galle, W. (2003). "E-purchasing: profiles of adopters and nonadopters", Industrial Marketing Management, 32, 227-33.

Mintzberg, H. (1979). Patterns in strategy formation. International Studies of Management\& Organization, 9(3), 67-86.

Moran, J. W. and Brightman, B. K. (2001). 'Leading organizational change', Career Development International, $6(2), 111-118$.

Neves, P., \& Caetano, A. (2009). Commitment to change: Contributions to trust in the supervisor and work outcomes. Group \& Organization Management, 34(6), 623-644.

Norman, D.A. (1998). The Invisible Computer, MIT Press, Cambridge, MA, .

Norman, G. (2010). Likert scales, levels of measurement and the "laws" of statistics. Advances in Health Sciences Education, 15(5), 625-632.

Northouse, P. G. (2007). Leadership theory and practice. Thousand Oaks, CA: Sage Publications, Inc.

Pallant, J. (2007). SPSS Survival Manual. London: Open University Press.

Pearce, J. A., and Robinson, R. B. (2003), Strategic Management: Formulation, Implementation, and Control. McGraw - Hill Irwin. New York

Proch, J., Elad - Strenger, J. and Kessler, T. (2019), Liberalism and Conservatism, for a Change! Rethinking the Association Between Political Orientation and Relation to Societal Change. Political Psychology, 40, 877903. doi:10.1111/pops. 12559

Rafferty, A.E., Jimmieson, N.L. and Armenakis, A.A. (2013) Change Readiness: A Multilevel Review. Journal of Management, 39, 110-135.

Rogers, E. M. (1995). Diffusion of innovations (4th ed.). New York: The Free Press.

Reed, Richard \& Lemak, David \& Mero, Neal. (2000). Total Quality Management and Sustainable Competitive Advantage. Journal of Quality Management. 5. 5-26. 10.1016/S1084-8568(00)00010-9.

Rouse, W. B. (2011). Necessary competencies for transforming an enterprise. Journal of Enterprise Transformation, 1(1), 71-92.

Senturia, T, Flees, L \& Maceda, M. (2008). Leading change management requires sticking to the PLOT.

Senior, B., \& Fleming, J. (2006). Organizational Change. London: Prentice Hall.

Shirani, A., Aiken, M., Reithel, B. (1994). "A model of user information satisfaction", Database, 25(4), 17-23.

Singh, A., \&Shoura, M. M. (2006). A life cycle evaluation of change in an engineering organization: A case study. International Journal of Project Management, 24(4), 337-348.

Sink, D. S., \& Tuttle, T. C. (1989). Planning and measurement in your organization of the future. Norcross, GA: Industrial Engineering and Management Press.

Sink, D. S., Johnston, C. S., \& Morris, W. T. (1995). By what method? Are you, developing the knowledge and skills to lead large-scale quality? Norcross, GA: Industrial Engineering and Management Press: Institute of Industrial Engineers.

Smith, M. E. (2002). Implementing organizational change: Correlates of success and failure. Performance Improvement Quarterly, 15(1), 67-83.

Soderholm, L. G. (1989). Needed: Engineering leadership. Design News, 45(13), 13-13.

Thompson, J. D. (1967). Organizations in action; social science bases of administrative theory. New York: McGraw-Hill.

Suresh, H. (2001). Change Management. Must for today’s Organization. Coimbatore: Think Business Networks Pvt. Ltd

Taherdoost, H., Sahibuddin, S., Jalaliyoon, N., Taherdoost, H., Sahibuddin, S., Jalaliyoon, N., Factor, E., Taherdoost, H., Sahibuddin, S., \& Jalaliyoon, N. (2020). Exploratory Factor Analysis; Concepts and Theory To cite this version: HAL Id: hal-02557344 Exploratory Factor Analysis; Concepts and Theory.

Turner, R. J. (1999). The Handbook of Project Based Management, (1st ed.). London, McGraw-Hill.

van den Heuvel, M., Demerouti, E., Bakker, A. B., \& Schaufeli, W. B. (2013). Adapting to change: The value of change information and meaning-making. Journal of Vocational Behavior, 83(1), 11-21.

Weber, P. S., \& Weber, J. E. (2001). Changes in employee perceptions during organizational change. Leadership \& Organization Development Journal, 22(6), 291-300.

Weiner, Y. (2018). Totally Serious Ways to Create a Great Work Culture. Retrieved from https://medium.com/thrive-global/99-totally-serious-ways-to-create-a-great-work-culturee7d093bdad23

Westwood, R., \& Linstead, S. (Eds.). (2001). The language of organization. London: Sage.

Winston, A. W. (2004). Engineering management -- A personal perspective. IEEE Transactions on Engineering Management, 51(4), 412-413.

Worren, N. A. M., Ruddle, K., \& Moore, K. (1999). From organizational development to change management: 
The emergence of a new profession. Journal of Applied Behavioral Science, 35(3), 273-286.

Wouters, M., \& Sportel, M. (2005). The role of existing measures in developing and implementing performance measurement systems

Zook, C. (2007). Finding your next CORE business. Harvard Business Review,85(4), 66-75.

\section{Appendices}

Appendix .A. Correlation Analysis

\begin{tabular}{|c|c|c|c|c|c|c|}
\hline \multicolumn{7}{|c|}{ Correlations } \\
\hline & & $\begin{array}{l}\text { leadership } \\
\text { composite } \\
\text { index }\end{array}$ & $\begin{array}{l}\text { Internal } \\
\text { communication } \\
\text { index }\end{array}$ & $\begin{array}{l}\text { organizational } \\
\text { culture index }\end{array}$ & $\begin{array}{l}\text { Information } \\
\text { technology } \\
\text { index }\end{array}$ & $\begin{array}{l}\text { Organizational } \\
\text { change } \\
\text { management } \\
\text { method index }\end{array}$ \\
\hline $\begin{array}{l}\text { leadership } \\
\text { composite index }\end{array}$ & $\begin{array}{c}\text { Pearson } \\
\text { Correlation }\end{array}$ & 1 & -.125 & $.159^{*}$ & .128 & $.326^{* *}$ \\
\hline $\begin{array}{l}\text { Internal } \\
\text { communication } \\
\text { index }\end{array}$ & $\begin{array}{c}\text { Pearson } \\
\text { Correlation }\end{array}$ & -.125 & 1 & .009 & $.163^{*}$ & .147 \\
\hline $\begin{array}{l}\text { organizational } \\
\text { culture index }\end{array}$ & $\begin{array}{c}\text { Pearson } \\
\text { Correlation }\end{array}$ & $.159^{*}$ & .009 & 1 & .018 & $.283^{* *}$ \\
\hline $\begin{array}{l}\text { Information } \\
\text { technology index }\end{array}$ & $\begin{array}{c}\text { Pearson } \\
\text { Correlation }\end{array}$ & .128 & $.163^{*}$ & .018 & 1 & .036 \\
\hline $\begin{array}{l}\text { Organizational } \\
\text { change } \\
\text { management } \\
\text { method index }\end{array}$ & $\begin{array}{c}\text { Pearson } \\
\text { Correlation }\end{array}$ & $.326^{* *}$ & .147 & $.283^{* *}$ & .036 & 1 \\
\hline
\end{tabular}

Source: Computed from own survey data, 2019

Appendix B.Total Statistics for Composite Factors Construction

\begin{tabular}{|c|c|c|}
\hline $\begin{array}{c}\text { S. } \\
\text { No. }\end{array}$ & Item-Total Statistics for Leadership Index Construct & $\begin{array}{c}\text { Cronbach's } \\
\text { Alpha if } \\
\text { Item } \\
\text { Deleted }\end{array}$ \\
\hline 1 & Leaders influenced the major decisions during the change project & 0.847 \\
\hline 2 & Top leadership commits resources and support necessary for change success & 0.826 \\
\hline 3 & Top leadership create and share the organizational goal with employee & 0.816 \\
\hline 4 & Top leadership support in employee participation in job related decision making & 0.819 \\
\hline 5 & Leadership guidance on change implementation process & 0.822 \\
\hline 6 & Lack of proper knowledge by top leaders & 0.882 \\
\hline & \multicolumn{2}{|l|}{ Item-Total Statistics for Internal Communication Index } \\
\hline 1 & Change management is communicated effectively within the department & 0.798 \\
\hline 2 & There is mutual relationship among the workers, which enables communication & 0.759 \\
\hline 3 & Some failure in internal communication have sometimes led to failure of change success & 0.784 \\
\hline 4 & There is clear vision that governs change in the organization & 0.777 \\
\hline 5 & Leadership influences the change implementation practices & 0.774 \\
\hline \multirow[t]{2}{*}{6} & There is adequate training to enable employees cope with the change implementation & 0.831 \\
\hline & \multicolumn{2}{|l|}{ Item-Total Statistics for Organizational Culture Index } \\
\hline 1 & The institution's culture is consistent with the change implementation strategy & 0.68 \\
\hline 2 & The institution's culture is a powerful driving force in implementing of change & 0.699 \\
\hline 3 & Employees have positive attitude towards change & 0.637 \\
\hline \multirow[t]{2}{*}{4} & Employees have resistance towards change & 0.805 \\
\hline & \multicolumn{2}{|l|}{ Item-Total Statistics for Information Communication Technology Index } \\
\hline 1 & Installation of new IT system poses financial challenge in the change & 0.824 \\
\hline 2 & Lack of proper knowledge on IT poses a challenge in change implementation & 0.773 \\
\hline
\end{tabular}




\begin{tabular}{|c|c|c|}
\hline $\begin{array}{c}\text { S. } \\
\text { No. }\end{array}$ & Item-Total Statistics for Leadership Index Construct & $\begin{array}{l}\text { Cronbach's } \\
\text { Alpha if } \\
\text { Item } \\
\text { Deleted }\end{array}$ \\
\hline 3 & Mismatch between software tools and organization need challenges the success of change & 0.762 \\
\hline 4 & Compatibility of the different systems cause a challenge in the success of change & 0.773 \\
\hline \multirow[t]{2}{*}{5} & Low technological learning ability poses financial challenge in the change & 0.809 \\
\hline & \multicolumn{2}{|l|}{ Item-Total Statistics for Change Success Construct } \\
\hline 1 & Organizational change projects have completed within the predetermined schedule & 0.888 \\
\hline 2 & The change projects have completed within the allocated budget & 0.894 \\
\hline 3 & All desired goals and objectives of the change projects have accomplished & 0.87 \\
\hline 4 & Organization's employees were sincerely satisfied with the change project results & 0.892 \\
\hline 5 & The change project actions were strongly integrated with every day activities & 0.882 \\
\hline 6 & The changes were properly implemented by addressing the situation & 0.873 \\
\hline 7 & $\begin{array}{l}\text { The performance of the project on solving the identified problem were accurately } \\
\text { measured }\end{array}$ & 0.888 \\
\hline \multirow[t]{2}{*}{8} & $\begin{array}{l}\text { Employee has trained properly to overcome gaps in skills and knowledge needed to } \\
\text { successfully implement the change }\end{array}$ & 0.884 \\
\hline & \multicolumn{2}{|l|}{ Item-Total Statistics for Change Management Method } \\
\hline 1 & The change situation that needed to be addressed were clearly identified & 0.726 \\
\hline 2 & The situation to what changes needed were analyzed & 0.704 \\
\hline 3 & Top management is committed to change management practice in the organization & 0.686 \\
\hline 4 & The change projects were aligned with the overall mission of organization well & 0.822 \\
\hline 5 & Change project were aligned with the overall mission of the organization & 0.703 \\
\hline
\end{tabular}

